\title{
Protected maleimide building blocks for the decoration of peptides, peptoids and peptide nucleic acids
}

\begin{tabular}{|r|l|}
\hline Journal: & Bioconjugate Chemistry \\
\hline Manuscript ID: & bc-2013-000614.R2 \\
\hline Danuscript Type: & Technical Note \\
\hline Complete List of Authors: & $\begin{array}{l}\text { Grandas, Anna; University of Barcelona, Organic Chemistry } \\
\text { Elduque, Xavier; University of Barcelona, Organic Chemistry } \\
\text { Sanchez, Albert; University of Barcelona, Organic Chemistry } \\
\text { Sharma, Kapil; University of Barcelona, Organic Chemistry } \\
\text { Pedroso, Enrique; University of Barcelona, Organic Chemistry }\end{array}$ \\
\hline \hline
\end{tabular}

\section{SCHOLARONE}

Manuscripts 


\title{
PROTECTED MALEIMIDE BUILDING BLOCKS FOR THE DECORATION OF PEPTIDES, PEPTOIDS AND PEPTIDE NUCLEIC ACIDS
}

\author{
Xavier Elduque, ${ }^{\#}$ Albert Sánchez, ${ }^{\#}$ Kapil Sharma, Enrique Pedroso and Anna Grandas* \\ Albert Sánchez, Enrique Pedroso and Anna Grandas* \\ Departament de Química Orgànica and IBUB, Facultat de Química, Universitat de \\ Barcelona; Martí i Franquès 1-11, 08028 Barcelona, Spain \\ Phone: +34934021263 \\ Fax: +34933397878 \\ e-mail: anna.grandas@ub.edu
}

${ }^{\#}$ These two authors contributed equally to this work. 


\section{ABSTRACT}

Monomers allowing for the introduction of [2,5-dimethylfuran]-protected maleimides into polyamides such as peptides, peptide nucleic acids and peptoids were prepared, as well as the corresponding oligomers. Suitable maleimide deprotection conditions were established in each case. The stability of the adducts generated by Michael-type maleimide-thiol reaction and Diels-Alder cycloaddition to maleimide deprotection conditions was exploited to prepare a variety of conjugates from peptide and PNA scaffolds incorporating one free and one protected maleimide. The target molecules were synthesized by using two subsequent maleimide-involving click reactions separated by a maleimide deprotection step. Carrying out maleimide deprotection and conjugation simultaneously gave better results than performing the two reactions subsequently.

\section{INTRODUCTION}

Controlled ligation of different building blocks provides access to complex structures, libraries of products, and biomolecules modified à la carte. Biocompatible materials, ${ }^{1,2}$ polymers with pharmacological application, ${ }^{3}$ new drugs with higher affinity and specificity for the target, ${ }^{4,5}$ biomolecules with optimized properties (increased half life in biological fluids, enhanced uptake, incorporating reporter groups for imaging, etc.), ${ }^{6}$ and complex nanostructures and supramolecular systems ${ }^{7,8}$ have been prepared taking advantage of those chemical tools.

In the past few years different alternatives have been described for the modular construction of sophisticated molecules making use of so-called "click" reactions. ${ }^{9}$ One of the options consisted in attaching different alkynes to a scaffold, either combinations of strained and terminal alkynes, ${ }^{10}$ or of unprotected and orthogonally protected alkynes. ${ }^{11-14}$ Subsequent Huisgen reactions with azides, with or without $\mathrm{Cu}(\mathrm{I})$ or after the required deprotection treatment, allowed new building blocks to be placed where desired.

Other experiments also involving $\mathrm{Cu}(\mathrm{I})$-catalyzed Huisgen cycloadditions ${ }^{15-17}$ have made use of a scaffold with two different appending groups, an azide and either a group that can be transformed into azide or a latent 1,3-dipole. The alkyne-azide reaction was 
followed by functional group conversion (that is, transformation of the azide precursors into azides or of the latent 1,3-dipole into dipole), and this by the second cycloaddition. Chemoselective reactions have been subsequently performed on scaffolds derivatized with two or three different functional groups. Huisgen cycloadditions, oxime and hydrazone formation, and thiol-maleimide reactions have been some of the most commonly chosen orthogonal reactions. ${ }^{18-20}$ The thiol-ene and inverse electron-demand Diels-Alder reactions are becoming increasingly popular and have also been used in combination with other chemoselective processes. ${ }^{21-23}$

Finally, a combination of stepwise synthesis and attachment of different building blocks at different elongation stages also has allowed different moieties to be attached to a polyamide chain. $^{24,25}$

Maleimides are versatile molecules susceptible to be used in "click" reactions with thiols, as already mentioned, and with dienes. Unprotected maleimides are not compatible with basic, nucleophilic reagents, which may promote maleimide hydrolysis and/or add to the double bond. We have recently described that the exo cycloadduct obtained by reaction of an $\mathrm{N}$-alkylated maleimide with 2,5-dimethylfuran is stable to concentrated aqueous ammonia at room temperature, which can be exploited for the onresin synthesis of maleimido-oligonucleotides. ${ }^{26,27}{ }^{5}$ Maleimido-oligonucleotides were prepared by coupling derivatives incorporating protected maleimide cycloadducts followed by deprotection with ammonia and retro-Diels-Alder reaction.

The goal of this work was the preparation of maleimido-containing peptides, peptide nucleic acids (PNAs) and peptoids, and their use in conjugation reactions (Scheme 1).

Scheme 1.

Solid-phase synthesis of these polyamides requires reaction with bases, either to remove the Fmoc (9-fluorenylmethoxycarbonyl) temporary protecting group in the case of peptides and PNAs, or to incorporate the construction units during peptoid assembly using the submonomer strategy. ${ }^{28}$ Therefore, use of [2,5-dimethylfuran]-protected maleimide building blocks was expected to allow introduction of a maleimide unit into any position of the chain.

The first step was the preparation of monomers incorporating the protected maleimide moiety (Scheme 2), which were subsequently introduced into the corresponding oligomers. Maleimide deprotection provided fully reactive maleimides in all cases, as assessed by reaction with thiol- or diene-containing compounds (Scheme 3). 
Assessment of the stability of the adducts generated after Michael-type and Diels-Alder reactions to maleimide deprotection conditions prompted us to attach protected and unprotected maleimides to the same polyamide scaffold (peptide, PNA), and use them for two subsequent maleimide-involving click reactions (Scheme 4). This methodology offers so far unexplored possibilities for the chemical preparation of libraries of compounds.

\section{MATERIALS AND METHODS}

General materials and methods (origin of products, procedures for solid-phase polyamide assembly, and conditions for the analysis and characterization of the different synthesized compounds) are described at the Supporting Information.

Scheme 2

[Protected maleimido]propanoic acid $\boldsymbol{N}$-hydroxysuccinimido ester 2 . To a solution of 1 (1.04 g, $3.91 \mathrm{mmol})$ in DCM (dichloromethane, $7.5 \mathrm{~mL}), \mathrm{EDC} \cdot \mathrm{HCl}$ ( $N$-ethyl- $N$ '-(3dimethylaminopropyl)-carbodiimide, $820 \mathrm{mg}, 4.3 \mathrm{mmol}$ ) and $N$-hydroxysuccinimide (490 mg, $4.3 \mathrm{mmol}$ ) was added. The mixture was stirred at room temperature for $84 \mathrm{~h}$. The reaction mixture was diluted with DCM to $75 \mathrm{~mL}$, and the resulting solution was washed with $0.1 \mathrm{M} \mathrm{HCl}(2 \times)$. The organic fraction was dried over anh. $\mathrm{MgSO}_{4}$ and filtered, and the solvent was removed in vacuo. A white foam was obtained $(1.23 \mathrm{~g}$, $84 \%$ ). The product was pure enough to be used in the next step. If required, 2 can be purified by silica gel column chromatography eluting with a 1:1 mixture of hexanes/AcOEt and increasing amounts of AcOEt (up to 100\%).

$\mathrm{Rf}=0.7(\mathrm{AcOEt}) ;{ }^{1} \mathrm{H}-\mathrm{NMR}\left(400 \mathrm{MHz}, \mathrm{CDCl}_{3}\right): \delta 6.30(\mathrm{~s}, 2 \mathrm{H}), 3.88(\mathrm{t}, J=7.23 \mathrm{~Hz}$, 2H), $2.98(\mathrm{t}, J=7.24 \mathrm{~Hz}, 2 \mathrm{H}), 2.88(\mathrm{~s}, 2 \mathrm{H}), 2.81(\mathrm{~s}, 4 \mathrm{H}), 1.70(\mathrm{~s}, 6 \mathrm{H}) \mathrm{ppm} ;{ }^{13} \mathrm{C}-\mathrm{NMR}$ $\left(101 \mathrm{MHz}, \mathrm{CDCl}_{3}\right): \delta 174.4,168.9,165.8,140.8,87.6,77.3,52.5,33.7,28.8,25.5$, 15.7; HRMS (ESI, positive mode): $m / z 363.1209[\mathrm{M}+\mathrm{H}]^{+}, 380.1441\left[\mathrm{M}+\mathrm{NH}_{4}\right]^{+}$, $747.2128[2 \mathrm{M}+\mathrm{Na}]^{+}, \mathrm{M}$ calcd. for $\mathrm{C}_{17} \mathrm{H}_{18} \mathrm{~N}_{2} \mathrm{O}_{7} 362.1114$.

Na-Fmoc-Lys(NE-[protected maleimido]propanoyl)-OH 3. $N \alpha$-Fmoc-Lys-OH (254 $\mathrm{mg}, 0.69 \mathrm{mmol})$ was dissolved in a mixture of trifluoroethanol $(8 \mathrm{~mL})$, THF 
(tetrahydrofuran, $4 \mathrm{~mL}$ ) and DIEA ( $N, N$-diisopropylethylamine, $0.36 \mathrm{~mL}, 2.1 \mathrm{mmol}) .2$ (300 $\mathrm{mg}, 0.83 \mathrm{mmol}$ ) was added to the solution, and the mixture was stirred for $24 \mathrm{~h}$ at room temperature, and for 5 days at $5{ }^{\circ} \mathrm{C}$. After the solvent was removed in vacuo, the crude was dissolved in AcOEt and washed with a 10\% aqueous solution of citric acid (3 $\times$ ). The organic fraction was collected and dried over $\mathrm{MgSO}_{4}$ and filtered, and the solvent was removed under reduced pressure. Lysine derivative $\mathbf{3}$ was purified by silica gel column chromatography, eluting with AcOEt and $0.1 \% \mathrm{AcOH}$, and increasing amounts of $\mathrm{MeOH}$ (up to $10 \%$ ). The appropriate fractions were pooled and evaporated to dryness, to yield a white foam $(292.6 \mathrm{mg}, 69 \%)$.

$\mathrm{Rf}=0.4(\mathrm{AcOEt} / \mathrm{MeOH} / \mathrm{AcOH}$ 10:1:0.1); IR (ATR), v: 3345, 2934, 1691, 1529, 1444, 1215, $1167 \mathrm{~cm}^{-1} ;{ }^{1} \mathrm{H}-\mathrm{NMR}\left(400 \mathrm{MHz}, \mathrm{CDCl}_{3}\right): \delta 7.74$ (d, J=7.54 Hz, 2H), 7.59 (t, $J=$ $6.80 \mathrm{~Hz}, 2 \mathrm{H}), 7.38$ (t, $J=7.45 \mathrm{~Hz}, 2 \mathrm{H}), 7.29(\mathrm{t}, J=7.43 \mathrm{~Hz}, 2 \mathrm{H}), 6.26$ (s, 2H), 4.37 (d, $J=7.07 \mathrm{~Hz}, 2 \mathrm{H}), 4.20(\mathrm{t}, J=6.90 \mathrm{~Hz}, 1 \mathrm{H}), 3.75(\mathrm{t}, J=7.06 \mathrm{~Hz}, 2 \mathrm{H}), 3.22$ (d, $J=5.73$ $\mathrm{Hz}, 2 \mathrm{H}), 2.81(\mathrm{~s}, 2 \mathrm{H}), 2.48(\mathrm{t}, J=6.97 \mathrm{~Hz}, 2 \mathrm{H}), 1.66(\mathrm{~s}, 6 \mathrm{H}), 2-0.8(\mathrm{bs}, 6 \mathrm{H}) \mathrm{ppm} ;{ }^{13} \mathrm{C}-$ NMR (101 MHz, $\left.\mathrm{CDCl}_{3}\right): \delta 143.7,141.3,140.8,127.7,127.1,125.1,120.0,87.7,67.0$, 52.5, 47.1, 39.0, 35.1, 34.3, 29.7, 28.6, 15.8 ppm; MALDI-TOF MS (DHB=2,5-

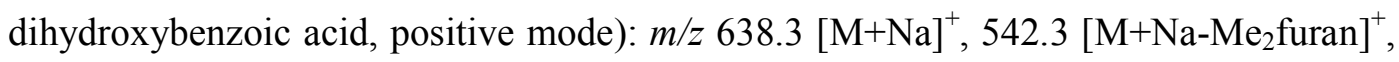
520.3 [M+H-furan] ${ }^{+}$, M calcd. for $\mathrm{C}_{34} \mathrm{H}_{37} \mathrm{~N}_{3} \mathrm{O}_{8}$ 615.3. HRMS (ESI, negative mode): $\mathrm{m} / z$ 614.2481 [M-H] ${ }^{-}$, M calcd. for $\mathrm{C}_{34} \mathrm{H}_{37} \mathrm{~N}_{3} \mathrm{O}_{8} 615.2581$.

\section{$N$-[Protected maleimido]- $N$-(2-Fmoc-aminoethyl)glycine tert-butyl ester 4. $\mathrm{N}$-(2-} Fmoc-aminoethyl)glycine tert-butyl ester $\cdot \mathrm{HCl}(890 \mathrm{mg}, 2.06 \mathrm{mmol})$ was dissolved in DCM $(120 \mathrm{~mL})$ and washed with a saturated $\mathrm{NaHCO}_{3}$ aqueous solution $(3 \times 50 \mathrm{~mL})$. The organic solution was dried over anh. $\mathrm{Na}_{2} \mathrm{SO}_{4}$ and filtered, and the solvent was removed in vacuo. The resulting yellowish oil (810 $\mathrm{mg}$ of $N$-(2-Fmocaminoethyl)glycine tert-butyl ester, quantitative recovery) was dissolved in DMF $(N, N$ dimethylformamide, $3 \mathrm{~mL}$ ) and bubbled with Ar. To this solution was added a mixture containing 1 (610 mg, $2.30 \mathrm{mmol}$ ), HOBt $\cdot \mathrm{H}_{2} \mathrm{O}$ (1-hydroxybenzotriazole, $544 \mathrm{mg}, 3.55$ mmol), HATU (2-(7-aza-1H-benzotriazole-1-yl)-1,1,3,3-tetramethyluronium hexafluorophosphate, $873 \mathrm{mg}, 2.30 \mathrm{mmol})$ and $N$-methylmorpholine $(410 \mu \mathrm{L}, 3.73$ mmol) previously stirred at room temperature under an Ar atmosphere for $20 \mathrm{~min}$. The resulting mixture was stirred for $60 \mathrm{~h}$ at room temperature under an Ar atmosphere. Solvent was removed under reduced pressure, and the resulting crude was purified by 
silica gel column chromatography eluting with a 1:1 (v/v) hexanes/AcOEt mixture. 4 Was obtained as a pale yellowish oil (1.06 g, $80 \%$ overall yield).

${ }^{1} \mathrm{H}-\mathrm{NMR}\left(400 \mathrm{MHz}, \mathrm{CDCl}_{3}\right.$ ): $\delta 7.75(\mathrm{~d}, J=7.6 \mathrm{~Hz}, 2 \mathrm{H}), 7.61(\mathrm{t}, J=8.4 \mathrm{~Hz}, 2 \mathrm{H}), 7.39$ (t, $J=7.4 \mathrm{~Hz}, 2 \mathrm{H}), 7.31(\mathrm{t}, J=7.4 \mathrm{~Hz}, 2 \mathrm{H}), 6.28(\mathrm{~s}, 2 \mathrm{H}), 5.97(\mathrm{t}, J=6.2 \mathrm{~Hz})$ and $5.64(\mathrm{t}$, $J=5.4 \mathrm{~Hz})$ (rotamers, $1 \mathrm{H}), 4.37(\mathrm{~m}, 2 \mathrm{H}), 4.23(\mathrm{~m}, 1 \mathrm{H}), 3.89(\mathrm{~s}, 1 \mathrm{H}), 3.80(\mathrm{~m}, 2 \mathrm{H}), 3.47$ $(\mathrm{m}, 2 \mathrm{H}), 3.35(\mathrm{~m}, 2 \mathrm{H}), 2.80(\mathrm{~s}, 6 \mathrm{H}), 2.64(\mathrm{t}, J=7.6 \mathrm{~Hz}), 2.52(\mathrm{t}, J=7.1 \mathrm{~Hz})$ (rotamers, 2H), 1.68 (s, 9H) ppm; ${ }^{13} \mathrm{C}-\mathrm{NMR}\left(101 \mathrm{MHz}, \mathrm{CDCl}_{3}\right): \delta 176.2,166.1,63.4,61.7,57.0$, 43.9, 41.0, 36.7, 29.8, 29.5, 26.8, 24.5 ppm; HRMS (ESI, positive mode): $\mathrm{m} / z 644.2955$ $[\mathrm{M}+\mathrm{H}]^{+}, 661.3227\left[\mathrm{M}+\mathrm{NH}_{4}\right]^{+}, 666.2782[\mathrm{M}+\mathrm{Na}]^{+}, 1304.6093\left[2 \mathrm{M}+\mathrm{NH}_{4}\right]^{+}, 1309.5680$ $[2 \mathrm{M}+\mathrm{Na}]^{+}, \mathrm{M}$ calcd. for $\mathrm{C}_{36} \mathrm{H}_{41} \mathrm{~N}_{3} \mathrm{O}_{8} 643.2887$.

$\boldsymbol{N}$-[Protected maleimido]- $\boldsymbol{N}$-(2-Fmoc-aminoethyl)glycine 5. A solution of 4 (500 mg, $0.777 \mathrm{mmol})$ in DCM $(10 \mathrm{~mL})$ was chilled in an ice bath. TFA (trifluoroacetic acid, 5 $\mathrm{mL}$ ) and TIS (triisopropylsilane, $2 \mathrm{~mL}$ ) was added, and the mixture was left to react at 0 ${ }^{\circ} \mathrm{C}$ for $30 \mathrm{~min}$ and then at room temperature until TLC analysis (hexanes/AcOEt 1:4, Rf $=0.21)$ showed complete disappearance of 4 (3 h reaction time). Solvent and reagents were removed in vacuo, and the resulting oil was dissolved in the minimal amount of DCM and precipitated over cold hexanes. A white solid was obtained after decantation (455 mg, quantitative yield), which was thoroughly dried in a desiccator before its use in PNA synthesis.

IR (ATR), v: 3349, 2937, 1768, 1694, 1523, 1446, 1403, $1170 \mathrm{~cm}^{-1} ;{ }^{1} \mathrm{H}-\mathrm{NMR}$ (400 $\left.\mathrm{MHz}, \mathrm{CDCl}_{3}\right): \delta 7.74(\mathrm{~d}, J=7.5 \mathrm{~Hz}, 2 \mathrm{H}), 7.59(\mathrm{~d}, J=5.5 \mathrm{~Hz}, 2 \mathrm{H}), 7.38(\mathrm{t}, J=7.3 \mathrm{~Hz}$, 2H), $7.30(\mathrm{t}, J=6.7 \mathrm{~Hz}, 2 \mathrm{H}), 6.27$ and $6.26(2 \mathrm{~s}, 2 \mathrm{H}), 5.78$ (brs) and 5.69 (brs) (rotamers, 1H), 4.60 (brs) and 4.54 (brs) (rotamers, $1 \mathrm{H}), 4.37(\mathrm{~m}, 2 \mathrm{H}), 4.21(\mathrm{t}, J=6.4$ Hz, 1H), 4.03 (m, 2H), 3.76 (brs, 4H), 3.49 (brs, 2H), 3.35 (brs, 2H), 2.80 (m, 2H), 2.68 (brs) and 2.55 (brs) (rotamers, $2 \mathrm{H}), 1.66(\mathrm{~s}, 6 \mathrm{H}) \mathrm{ppm} ;{ }^{13} \mathrm{C}-\mathrm{NMR}\left(101 \mathrm{MHz}, \mathrm{CDCl}_{3}\right): \delta$ 174.7, 172.6, 171.7, 156.7, 143.9, 141.3, 140.9, 127.7, 127.1, 125.1, 120.0, 87.6, 67.0, 52.5, 49.5, 49.2, 47.1, 39.4, 34.9, 30.1, 15.9 ppm; HRMS (ESI, positive mode): $\mathrm{m} / \mathrm{z}$ $588.2328[\mathrm{M}+\mathrm{H}]^{+}, 605.2599\left[\mathrm{M}+\mathrm{NH}_{4}\right]^{+}, 610.2159[\mathrm{M}+\mathrm{Na}]^{+}, 1175.4609[2 \mathrm{M}+\mathrm{H}]^{+}$, $1192.4849\left[2 \mathrm{M}+\mathrm{NH}_{4}\right]^{+}, 1197.4380[2 \mathrm{M}+\mathrm{Na}]^{+}, \mathrm{M}$ calcd. for $\mathrm{C}_{32} \mathrm{H}_{33} \mathrm{~N}_{3} \mathrm{O}_{8} 587.2261$.

2,5-Dimethylfuran-protected maleimide (exo + endo) 6. Maleimide (3.0 g, 30.9 mmol) was dissolved in ACN (acetonitrile, $55 \mathrm{~mL}$ ). The solution was heated to $60{ }^{\circ} \mathrm{C}$, 
and 2,5-dimethylfuran $(8.3 \mathrm{~mL}, 77.3 \mathrm{mmol})$ was added. After overnight reaction at 60 ${ }^{\circ} \mathrm{C}$, the mixture was evaporated to dryness to yield 6 as a $4: 1$ mixture of exo and endo isomers.

Exo isomer: ${ }^{1} \mathrm{H}-\mathrm{NMR}\left(400 \mathrm{MHz}, \mathrm{CDCl}_{3}\right): \delta 6.31(\mathrm{~s}, 2 \mathrm{H}), 2.88(\mathrm{~s}, 2 \mathrm{H}), 1.73(\mathrm{~s}, 6 \mathrm{H})$ ppm; ${ }^{13} \mathrm{C}-\mathrm{NMR}\left(101 \mathrm{MHz}, \mathrm{CDCl}_{3}\right): \delta 175.0,140.9,87.7,53.8,15.8 \mathrm{ppm}$.

Endo isomer: ${ }^{1} \mathrm{H}-\mathrm{NMR}\left(400 \mathrm{MHz}, \mathrm{CDCl}_{3}\right): \delta 6.31(\mathrm{~s}, 2 \mathrm{H}), 3.27(\mathrm{~s}, 2 \mathrm{H}), 1.78(\mathrm{~s}, 6 \mathrm{H})$ ppm; ${ }^{13} \mathrm{C}-\mathrm{NMR}\left(101 \mathrm{MHz}, \mathrm{CDCl}_{3}\right): \delta 174.4,138.2,135.1,54.9,18.5 \mathrm{ppm}$.

HRMS (ESI, positive mode): $m / z$ 194.0915 [M+H] $]^{+}, \mathrm{M}$ calcd. for $\mathrm{C}_{10} \mathrm{H}_{11} \mathrm{NO}_{3} 193.0739$.

$\mathrm{N}$-Boc-ethanolamine $7 .^{29}$ Ethanolamine $(6.1 \mathrm{~g}, 0.1 \mathrm{~mol})$ was added to $\mathrm{Boc}_{2} \mathrm{O}$ (Boc=tert-butoxycarbonyl, $21.8 \mathrm{~g}, 0.1 \mathrm{~mol}$ ) in three portions at $0{ }^{\circ} \mathrm{C}$ over $10 \mathrm{~min}$, and the mixture was stirred for $2 \mathrm{~h}$. A colorless precipitate formed with the evolution of heat. After filtration, the solid was purified by silica gel column chromatography eluting with a 6:1 hexanes/AcOEt mixture. The desired fractions (as assessed by TLC: hexanes/AcOEt 2:3, $\mathrm{Rf}=0.5$, detection: reaction with anisaldehyde) were pooled and taken to dryness, which yielded pure 7 as a colorless oil (15.8 g, $98 \%$ ).

${ }^{1} \mathrm{H}-\mathrm{NMR}\left(400 \mathrm{MHz}, \mathrm{CDCl}_{3}\right): \delta 5.05$ (bs, 1H), 3.68 (m, 2H), 3.26 (t, 2H, $J=4.8 \mathrm{~Hz}$ ), 2.83 (bs, 1H), 1.43 (s, 9H) ppm; ${ }^{13} \mathrm{C}-\mathrm{NMR}\left(101 \mathrm{MHz}, \mathrm{CDCl}_{3}\right): \delta$ 156.81, 79.63, 62.47, 43.10, $28.34 \mathrm{ppm}$.

$\boldsymbol{N}$-[Protected maleimido]-ethanediamine-TFA 9 (exo). A mixture of protected maleimide 6 (500 mg, $2.59 \mathrm{mmol}), N$-Boc-ethanolamine 7 (278 mg, $1.73 \mathrm{mmol})$ and triphenylphosphine (679 mg, $2.59 \mathrm{mmol}$ ) was coevaporated with anh. THF, dissolved in anh. THF (20 mL) and chilled in an ice bath. DIAD (diisopropylazodicarboxylate, 511 $\mu \mathrm{L}, 2.59 \mathrm{mmol}$ ) was added dropwise. The mixture was reacted for $2 \mathrm{~h}$ at $0{ }^{\circ} \mathrm{C}$ and overnight at room temperature, and then the solvent was removed under reduced pressure. The resulting residue (which contained the mixture of exo and endo isomers) was treated with a $2: 3 \mathrm{v} / \mathrm{v} \mathrm{MeOH} /$ conc. aq. ammonia mixture overnight, and then concentrated under reduced pressure. $\mathrm{CHCl}_{3}(20 \mathrm{~mL})$ was added, and the $\mathrm{pH}$ of the aqueous phase was adjusted to 12-13. The two phases were separated, and the organic phase was reextracted with $0.01 \mathrm{M} \mathrm{NaOH}(20 \mathrm{~mL}, 3 \times)$, dried over $\mathrm{MgSO}_{4}$ and taken to dryness. ${ }^{1} \mathrm{H}$ NMR analysis showed that the resulting residue contained $\mathbf{8}$ as the exo isomer, plus byproducts resulting from the Mitsunobu reaction (triphenylphosphine 
oxide and $\left.\mathrm{DIADH}_{2}\right)$. Crude 8 was treated with a 3:7 TFA/DCM mixture $(30 \mathrm{~mL})$ for $1 \mathrm{~h}$ at room temperature, and then was taken to dryness. The desired product precipitated upon addition of anhydrous diethyl ether $(2 \mathrm{~mL})$. After centrifugation the supernatant was discarded and diethyl ether was added again to the precipitate. This step was repeated three times. The product was dried thoroughly under reduced pressure, to afford pure 9 (119 $\mathrm{mg}, 20 \%)$.

8: ${ }^{1} \mathrm{H}-\mathrm{NMR}\left(400 \mathrm{MHz}, \mathrm{CDCl}_{3}\right): \delta 6.12(\mathrm{~s}, 2 \mathrm{H}), 3.44(\mathrm{t}, J=5.61 \mathrm{~Hz}, 2 \mathrm{H}), 3.10(\mathrm{~m}, 2 \mathrm{H})$, $2.65(\mathrm{~s}, 2 \mathrm{H}), 1.51(\mathrm{~s}, 6 \mathrm{H}), 1.22(\mathrm{~s}, 9 \mathrm{H}) \mathrm{ppm}$.

9: IR (ATR), v: 3574, 2985, 1769, 1694, 1674, 1402, 1200, 1167, $1124 \mathrm{~cm}^{-1}$; ${ }^{1} \mathrm{H}-\mathrm{NMR}$ (400 MHz, acetone- $\left.\mathrm{d}_{6}\right): \delta 6.38(\mathrm{~s}, 2 \mathrm{H}), 3.96$ (t, $\left.J=5.33 \mathrm{~Hz}, 2 \mathrm{H}\right), 3.83(\mathrm{t}, J=5.36 \mathrm{~Hz}, 2 \mathrm{H})$, $2.95(\mathrm{~s}, 2 \mathrm{H}), 1.59$ (s, 6H) ppm; ${ }^{13} \mathrm{C}-\mathrm{NMR}\left(101 \mathrm{MHz}\right.$, acetone- $\left.\mathrm{d}_{6}\right): \delta 176.8,142.7,89.2$, 54.8, 46.3, 38.3, 17.2 ppm; HRMS (ESI, positive mode): $m / z 473.2388[\mathrm{M}+\mathrm{H}]^{+}, \mathrm{M}$ calcd. for $\mathrm{C}_{24} \mathrm{H}_{32} \mathrm{~N}_{4} \mathrm{O}_{6} 472.2317$.

Syntheses of the conjugates involved the following series of steps:

a: Mono-derivatized polyamides. i) Elongation of polyamide chains by solid-phase synthesis, using commercially available building blocks and the protected maleimido monomers here described $(\mathbf{3}, \mathbf{5}$ and $\mathbf{9}$ were used to introduce the protected maleimide moieties at any position within the chain, 3-maleimidopropanoic acid $\mathbf{1}$ was only used for $N$-terminal derivatization); ii) acid treatment to remove all protecting groups except that on the maleimide moiety; iii) maleimide deprotection following one of the procedures described below; iv) conjugation (reaction with either a thiol or a diene, see below).

b: Doubly-derivatized polyamides. Steps i) and ii) were the same as above; iii) first conjugation (reaction of the free maleimide with either a thiol or a diene); iv) maleimide deprotection; v) second conjugation (second reaction with either a thiol or a diene).

c: Alternatively, in some cases maleimide deprotection and conjugation were carried out simultaneously (see below).

Microwave-promoted maleimide deprotection. This procedure was used to deprotect maleimides appending from PNAs.

A solution $(1000 \mu \mathrm{L})$ of [protected maleimido]-containing PNA in a $1: 1(\mathrm{v} / \mathrm{v})$ $\mathrm{MeOH} / \mathrm{H}_{2} \mathrm{O}$ mixture $(25 \mu \mathrm{M}$ concentration) was introduced in a microwave vial and 
irradiated for $60 \mathrm{~min}$ at $100{ }^{\circ} \mathrm{C}$. Solvent was removed under vacuum, and the resulting crude was dissolved in water for HPLC analysis and characterization by MALDI-TOF MS. The crude was used at the subsequent conjugation step without any purification.

Maleimide deprotection by heating in toluene. This procedure was used to deprotect maleimides appending from peptides and peptoids.

The [protected maleimido]-containing peptide/peptoid was dried by coevaporation with anh. toluene (3-4 $\times)$, and a new batch of anh. toluene was added (the amount that would be required to obtain a $25 \mu \mathrm{M}$ solution). The mixture was heated at $90{ }^{\circ} \mathrm{C}$, toluene was removed under reduced pressure, and the crude was dissolved in water for HPLC analysis and mass spectrometric characterization. The crude was used at the subsequent conjugation step without any purification.

Conjugation: General procedure for Michael-type reactions. Aliquots of aqueous (or aqueous-organic) solutions containing the required amounts of maleimidocontaining oligomer and the corresponding thiol-containing compound (5 to 10-fold molar excess) were mixed, and the mixture was diluted with $0.5 \mathrm{M}$ triethylammonium acetate, $\mathrm{pH}=7.8-7.9$ (final concentration of oligomer: $50-150 \mu \mathrm{M}$ ). The mixture was stirred at room temperature under an Ar atmosphere. Initially all experiments were carried out overnight; yet, we have verified that in most cases the reaction is complete in $1 \mathrm{~h}$ or even less. Shortening the reaction time prevents hydrolysis of the succinimide formed after the thiol-maleimide reaction, which has occasionally been observed (compound 21). Reaction crudes were analyzed by HPLC. Conjugates were purified by HPLC and characterized by MALDI-TOF MS.

When reagents were not soluble in water the reaction was carried out in organic solventaqueous buffer mixtures (see Supporting information, synthesis of conjugate 22).

Conjugation: General procedure for Diels-Alder cycloadditions. The maleimidocontaining oligomer and the diene-oligonucleotide were dissolved in water (final concentration of maleimido-containing oligomer: 50-250 $\mu \mathrm{M}$ ). The molar ratio varied between $1: 1$ and 1:5, the component in excess generally being the least valuable one, in other words, the most easily accessible (which of the two reagents is used in excess was found to have no influence on the reaction yield - data not shown). The mixture was 
reacted at $37{ }^{\circ} \mathrm{C}$, generally overnight. Reaction crudes were analyzed by HPLC. Conjugates were purified by HPLC and characterized by MALDI-TOF MS.

One-pot [maleimide deprotection + conjugation] reactions. After coevaporation with anh. toluene $(3 \times)$, the protected maleimido-containing polyamide, and either the diene (1-2 equiv) or the thiol-containing compound (10-fold molar excess) were dissolved or suspended in anh. toluene (concentration of the polyamide in the mixture: $25 \mu \mathrm{M}$ ). The mixture was reacted for $6 \mathrm{~h}$ at $90^{\circ} \mathrm{C}$, and then taken to dryness. HPLC analysis of the crudes (dissolved in water) showed complete deprotection of maleimides and high to quantitative conjugation yields.

This procedure was found to be a good alternative to accelerate cycloaddition reactions not completed even after days reaction time (preparation of conjugate 27, see Supporting Information).

\section{RESULTS AND DISCUSSION}

\section{Synthesis of [protected maleimido]-containing monomers.}

For the synthesis of the lysine derivative $\mathbf{3}$ (Scheme $2 \mathrm{a}$ ), the carboxyl group of $\mathbf{1}^{26}$ was activated to give $N$-hydroxysuccinimido ester $\mathbf{2}$, and subsequent reaction of $\mathbf{2}$ with the $\varepsilon$-amine of Fmoc-L-lysine linked the protected maleimide to the amino acid side chain and gave the target derivative 3 .

The PNA monomer 5 (Scheme 2b) was prepared by first reacting 1 with the secondary amine of $N$-(N-Fmoc-2-aminoethyl)glycine tert-butyl ester, which was followed by an acid treatment to deprotect the carboxyl group of 4 .

Scheme $2 \mathrm{c}$ summarizes the reactions carried out to obtain [protected maleimido]-amine 9. In the preliminary steps, 2,5-dimethylfuran-protected maleimide $(6$, mixture of exo and endo isomers) and $\mathrm{N}$-Boc-aminoethanol (7) were prepared. Then a DIAD/ $\mathrm{Ph}_{3} \mathrm{P}$ mediated Mitsunobu reaction between 6 and 7, followed by reaction with a 2:3 $\mathrm{MeOH} /$ conc. aq. ammonia mixture to get rid of the endo isomer ${ }^{26}$ afforded the fully protected maleimido-amine 8. Finally, removal of the Boc group by treatment with trifluoroacetic acid furnished amine 9 (trifluoroacetate salt). 
These [protected maleimido]-containing monomers were used in the solid-phase synthesis of peptide, PNA and peptoid polyamides following well-known procedures (see Supporting Information for experimental conditions, and Schemes S1-S3). Syntheses proceeded smoothly, showing that all derivatives behaved as standard building blocks.

\section{Maleimide deprotection and conjugation reactions with polyamides.}

Conditions for maleimide deprotection (retro-Diels-Alder reaction) were examined for the different polyamides. Peptide 10, PNA 14 and peptoid 18 (Scheme 3) were heated either in a metal block (suspension in toluene) or in a microwave oven $\left(\mathrm{MeOH} / \mathrm{H}_{2} \mathrm{O}\right.$ solution), and the resulting crudes were analyzed by HPLC.

Peptide 10 afforded fairly heterogeneous crudes. Best results were achieved by heating in toluene (Scheme 3a, a.1; Figure S2), but the yield was not very good, and the longer the reaction time the lower the quality of the crude.

In the case of the PNA chain (14, Scheme 3b, b.1), highly homogeneous maleimidoPNA crudes (15) were obtained with any of the two deprotection procedures, the yield being higher when using the microwave oven ( $>95 \%$, Figure S6) than when heating in toluene (ca. $70 \%$ ).

As to peptoid 18 (Scheme 3c, c.1), microwave irradiation did not afford a sufficiently satisfactory crude. Yet, heating in toluene provided the target maleimido-peptoid (19) in good yield (>90\%) and high purity (Figure S9).

Reaction (Scheme 3) of the maleimido-containing polyamides (peptide 11, PNA 15 and peptoid 19) with thiol- and diene-containing compounds (Figure 1) afforded the target conjugation products $(\mathbf{1 2}, \mathbf{1 6}, \mathbf{1 7}$, and 20-23; Figures S3b, S7 and S10) and confirmed that maleimide deprotection had afforded fully reactive maleimides in all cases.

Scheme 3, Figure 1

With the aim to improve the low yields associated with maleimide deprotection in peptides, we considered the possibility of carrying out one-pot deprotection and conjugation reactions, in other words, of deprotecting the maleimide in the presence of either the thiol or the diene. Previously, the stability of the adducts resulting from conjugation reactions (Michael thiol-ene and Diels-Alder) to maleimide deprotection 
conditions was verified using standard samples of conjugates 12 and 13 (see Supplementary Information, section 4). Both 12 and 13 remained undegraded, which indicated that maleimide deprotection conditions are compatible with maleimideinvolving conjugation reactions (Figure S13).

When peptide $\mathbf{1 0}$ was suspended in toluene and heated in the presence of glutathione over a period of $6 \mathrm{~h}$ (Scheme 3a, a.3), the target conjugate 12 was obtained in high yield and purity (Figure S3b). Likewise, conjugate $\mathbf{1 3}$ was the main product in the crude (Figure S4) when $\mathbf{1 0}$ and diene-dT $\mathrm{T}_{5}$ were reacted under the same conditions (Scheme 3a, a.4). These results suggest that the thiol or the diene present in the reaction medium drive the equilibrium of the retro-Diels-Alder reaction by trapping the free maleimide, and that the conjugation reaction is quick enough so as to prevent the maleimide from being degraded. Therefore, when the two reactions are simultaneously carried out the overall yield is higher, and the final conjugate is much more homogeneous. This result has also been exploited for the preparation of cyclic oligonucleotides. ${ }^{30}$

Both the Michael-type and Diels-Alder reactions provide conjugates containing succinimide rings (see structures in Schemes 1 and 3). These succinimides were fairly stable in aqueous media, with hydrolysis taking place only after several cycles of dissolving in water and lyophilization, except in the case of conjugate 21. 21 Could only be obtained if 19 was reacted with an excess (10 equiv) of biotin-SH for $5 \mathrm{~min}$, after which time the mixture had to be immediately frozen and lyophilized. Longer reaction times gave crudes in which the main product was the conjugate with the hydrolyzed succinimide. Conjugate 28 (see Scheme 4 and below) also underwent some hydrolysis (37\%) upon microwave-promoted maleimide deprotection.

Two maleimide-involving consecutive click reactions were carried out on peptide $\mathbf{2 4}$, PNA 31, and a PNA sequence described to exhibit antibactericidal antisense effects ${ }^{31}$ (39) (Scheme 4).

\section{Scheme 4}

Synthesis of conjugates differing in the position to which glutathione and diene- $\mathrm{dT}_{5}$ were linked to peptide 24 (Scheme 4a, 1.i and 2.i, Figures S15 and S16) involved, firstly, reactions with the $N$-terminal free maleimide, which yielded conjugates $\mathbf{2 5}$ and 28. 25 And 28 were then heated in toluene to deprotect the internal maleimides, providing compounds 26 and 29. Finally, reaction of $\mathbf{2 6}$ and 29 with diene-dT 5 and 
glutathione, respectively, afforded the doubly-derivatized regioisiomeric conjugates $\mathbf{2 7}$ and 30.

As in previous experiments, the maleimide deprotection yield was lower for the peptidepeptide conjugate (25) than for the peptide-oligonucleotide one (28). Yet, carrying out the deprotection and conjugation reactions simultaneously (Scheme 4a, 3.ii) significantly ameliorated (Figure S15d) both the deprotection and the conjugation yield (the room temperature cycloaddition providing $\mathbf{2 7}$ from $\mathbf{2 6}$ was extremely slow). Hence, and in agreement with the outcome of the experiments described above, the yield of maleimide deprotection in the presence of a maleimide-trapping compound was higher than in its absence. It is also worth noticing that maleimide deprotection (retro-DielsAlder reaction) and Diels-Alder conjugation can be simultaneously carried out because of the higher stability of diene-maleimide cycloadducts with respect to 2,5dimethylfuran-maleimide adducts.

As to PNA 31, the final conjugates resulted from combining either two Michael-type reactions, or, again, Michael and Diels-Alder reactions in either order (Scheme 4b). In the first case, conjugate 34 incorporated biotin and a 21-aminoacid peptide (Cyspeptide, Figure 1). In conjugate 35 the PNA scaffold was attached to biotin and a 10mer phosphorothioate oligonucleotide, while in $\mathbf{3 8}$ the 10-mer phosphorothioate oligonucleotide and the Cys-peptide were linked to the PNA chain (Figures S18 and S19).

Finally, the two ends of PNA 39 were successfully modified (Scheme 4c) using the same three-step conjugation/maleimide deprotection/conjugation procedure (Figure S20). Hence, this methodology is compatible with PNAs containing all of the four nucleobases, and allows PNAs to be derivatized and keep their full recognition potential.

The fact that no side reactions were detected during the preparation of conjugates $\mathbf{3 5}, \mathbf{3 8}$ and 43 further supports our previous conclusions on reactions involving thiophosphate diesters and maleimides. ${ }^{27}$ Both HPLC and mass spectrometric analyses (see Supplementary Information) are consistent with: i) phosphorothioate diesters not interfering with maleimide-diene Diels-Alder cycloadditions (reactions affording $\mathbf{3 5}$ and 43), ii) microwave-promoted maleimide deprotection of the [phosphorothioate oligonucleotide]-PNA conjugate cleanly affording the target compound (37), and iii) successful reaction of the resulting free maleimide with the Cys-peptide (to yield 38). 


\section{CONCLUSIONS}

2,5-Dimethylfuran-protected maleimide moieties suitable for use in the synthesis of [protected maleimido]-containing peptides, PNAs and peptoids were prepared and incorporated into the corresponding oligomers.

Best conditions for maleimide deprotection were found to vary depending on the oligomer, but in all cases fully reactive maleimides were obtained. Deprotection of peptide-linked maleimides was troublesome, since the reaction took place in low yield and was less clean than with PNAs and peptoids. Yet, these problems could be overcome by carrying out simultaneously maleimide deprotection and conjugation, since the adducts generated from Michael-type and Diels-Alder reactions remain stable under maleimide deprotection conditions. One-pot maleimide deprotection and conjugation furnished crudes substantially more homogeneous, increased the conjugation yield, and accelerated slow cycloadditions.

Finally, peptides and PNAs incorporating the new [protected maleimido]-containing derivatives and an unprotected maleimide at the $N$-terminal were employed as scaffolds to which two different units were appended. This dual conjugation was accomplished using either a three step conjugation/maleimide deprotection/conjugation procedure, or the two-step conjugation/[maleimide deprotection + conjugation] alternative process.

The methodology here described broadens the scope of possibilities available so far for the ligation of multiple components, the synthesis of complex molecular systems and libraries of differently decorated scaffolds, or to attach different labels or reporter groups to biomolecules (or their ligands). Decoration of a scaffold with different appendices is made possible simply by the introduction of two maleimides, one free and one protected. Moreover, incorporation of other functional groups can also be envisaged to allow for further derivatization, since the thiol-maleimide and the Diels-Alder reactions can be combined with other conjugation chemistries.

\section{ACKNOWLEDGMENTS}

This work was supported by funds from the Ministerio de Economía y Competitividad (grant CTQ2010-21567-C02-01, and the project RNAREG, grant CSD2009-00080, funded under the programme CONSOLIDER INGENIO 2010), and the Generalitat de 
Catalunya (2009SGR-208). A. S. and X. E. were recipient fellows of the Generalitat de Catalunya and the MINECO, respectively.

Supporting Information Available: General materials and methods; details on the synthesis of the different compounds and mass spectrometric characterization; assessment of the stability of Michael-type adducts and Diels-Alder cycloadducts to maleimide deprotection conditions; HPLC traces of crude maleimido-polyamides and derived conjugates. This information is available free of charge via the Internet at http://pubs.acs.org/.

\section{REFERENCES}

(1) DeForest, C. A., and Anseth, K. S. (2011) Cytocompatible click-based hydrogels with dynamically based tunable properties through orthogonal photoconjugation and photocleavage reactions. Nat. Chem. 3, 925-931.

(2) Jianwen, X. , Filion, T. M., Prifti, F., and Song, J. (2011) Cytocompatible poly(ethylene glycol)-co-polycarbonate hydrogels cross-linked by copper-free, strainpromoted click chemistry. Chem. Asian J. 6, 2730-2737.

(3) van Dijk, M., Rijkers, D. T. S., Liskamp, R. M. J., van Nostrum, C. F., and Hennink, W. E. (2009) Synthesis and applications of biomedical and pharmaceutical polymers via click chemistry methodologies. Bioconjugate Chem. 20, 2001-2016.

(4) Shelke, S. V., Cutting, B., Jiang, X., Koliwer-Brandl, H., Strasser, D. S., Schwardt, O., Kelm, S., and Ernst, B. (2010) A fragment-based in situ combinatorial approach to identify high-affinity ligands for unknown binding sites. Angew. Chem. Int. Ed. 49, 5721-5725.

(5) Guiard, J., Fiege, B., Kitov, P. I., Peters, T., and Bundle, D. R. (2011) "Doubleclick" protocol for synthesis of heterobifunctional multivalent ligands: toward a focused library of specific norovirus inhibitors. Chem. Eur. J. 17, 7438-744.

(6) Kalia, J., and Raines, R. T. (2010) Advances in bioconjugation. Curr. Org. Chem. $14,138-147$. 
(7) Schmidt, B. V., Fechler, N., Falkenhagen, J., and Lutz, J.-F. (2011) Controlled folding of synthetic polymer chains through the formation of positionable covalent bridges. Nat. Chem. 3, 234-238.

(8) Fahrenbach, A. C., and Stoddart, J. F. (2011) Reactions under the click chemistry philosophy employed in supramolecular and mechanostereochemical systems. Chem. Asian J. 6, 2660-2669.

(9) Kolb, H. C., Finn, M. G., and Sharpless, K. B. (2001) Click chemistry: diverse chemical function from a few good reactions. Angew. Chem. Int. Ed. 40, 2004-2012.

(10) Kele, P., Mezö, G., Achatz, D., and Wolfbeis, O. S. (2009) Dual labeling of biomolecules by using click chemistry: a sequential approach. Angew. Chem. Int. Ed. 48, 344-347.

(11) Aucagne, V., and Leigh, D. A. (2006) Chemoselective formation of successive triazole linkages in one pot: "click-click" chemistry. Org. Lett. 8, 4504-4507.

(12) Gramlich, P. M. E., Warncke, S., Gierlich, J., and Carell, T. (2008) Click-clickclick: single to triple modification of DNA. Angew. Chem. Int. Ed. 47, 3442-3444.

(13) Valverde, I. E., Delmas, A. F., and Aucagne, V. (2009) Click à la carte: robust semi-orthogonal alkyne protecting groups for multiple successive azide/alkyne cycloadditions. Tetrahedron 65, 7597-7602.

(14) Ledin, P. A., Friscourt, F., Guo, J., and Boons, G.-J. (2011) Convergent assembly and surface modification of multifunctional dendrimers by three consecutive click reactions. Chem. Eur. J. 17, 839-846.

(15) Pourceau, G., Meyer, A., Vasseur, J.-J., and Morvan, F. (2009) Synthesis of mannose and galactose oligonucleotide conjugates by bi-click chemistry. J. Org. Chem. 74, 1218-1222.

(16) Meyer, A., Pourceau, G., Vasseur, J.-J., and Morvan, F. (2009) 5'-Bis-conjugation of oligonucleotides by amidative oxidation and click chemistry. J. Org. Chem. 74, 6689-6692.

(17) Sanders, B. C., Friscourt, F., Ledin, P. A., Mbua, N. E., Arumugam, S., Guo, J., Boltje, T. J., Popik, V. V., and Boons, G.-J. (2011) Metal-free sequential [3+2]-dipolar cycloadditions using cyclooctynes and 1,3-dipoles of different reactivity. J. Am. Chem. Soc. 133, 949-957.

(18) Galibert, M., Dumy, P., and Boturyn, D. (2009) One-pot approach to well-defined biomolecular assemblies by orthogonal chemoselective ligations. Angew. Chem. Int. Ed. 48, 2576-2579. 
(19) Meyer, A., Spinelli, N., Dumy, P., Vasseur, J.-J., Morvan, F., and Defrancq, E. (2010) Oligonucleotide sequential bis-conjugation via click-oxime and click-Huisgen procedures. J. Org. Chem. 75, 3927-3930.

(20) Galibert, M., Renaudet, O., Dumy, P., and Boturyn, D. (2011) Access to biomolecular assemblies through one-pot triple orthogonal chemoselective ligations. Angew. Chem. Int. Ed. 50, 1901-1904.

(21) Gupta, N., Lin, B. F., Campos, L. M., Dimitriou, M. D., Hikita, S. T., Treat, N. D., Tirrell, M. V., Clegg, D. O., Kramer, E. J., and Hawker, C. J. (2010) A versatile approach to high-throughput microarrays usin thiol-ene chemistry. Nat. Chem. 2, 138145.

(22) Hoyle, C. E., and Bowman, C. N. (2010) Thiol-ene click chemistry. Angew. Chem. Int. Ed. 49, 1540-1573.

(23) Schoch, J., Staudt, M., Samanta, A., Wiessler, M., and Jäschke, A. (2012) Sitespecific one-pot dual labeling of DNA by orthogonal cycloaddition chemistry. Bioconjugate Chem. 23, 1382-1386.

(24) Holub, J. M., Jang, H., and Kirshenbaum, K. (2006) Clickity-click: highly functionalized peptoid oligomers generated by sequential conjugation reactions on solid-phase support. Org. Biomol. Chem. 4, 1497-1502.

(25) Pourceau, G., Meyer, A., Vasseur, J.-J., Morvan, F., Chevolot, Y., and Souteyrand, E. (2010) Oligonucleotide carbohydrate-centered galactosyl cluster conjugates synthesized by click and phosphoramidite chemistries. Bioconjugate Chem. 21, 15201529.

(26) Sánchez, A., Pedroso, E., and Grandas, A. (2011) Maleimide-dimethylfuran exo adducts: effective maleimide protection in the synthesis of oligonucleotide conjugates. Org. Lett. 13, 4363-4367.

(27) Sánchez, A., Pedroso, E., and Grandas, A. (2012) Conjugation reactions involving maleimides and phosphorothioate oligonucleotides. Bioconjugate Chem. 23, 300-307.

(28) Zuckermann, R. N., Kerr, J. M., Kent, S. B. H., and Moos, W. H. (1992) Efficient method for the preparation of peptoids [oligo(N-substituted glycines)] by submonomer solid-phase synthesis. J. Am. Chem. Soc. 114, 10646-10647.

(29) Jia, X., Huang, Q., Li, J, Li, S., and Yang, Q. (2007) Environmentally benign $N$ Boc protection under solvent- and catalyst-free conditions. Synlett 5, 806-808.

(30) Sánchez, A., Pedroso, E., and Grandas, A. (2013) Oligonucleotide cyclization: the thiol-maleimde reaction revisited. Chem. Commun. 49, 309-311. 
(31) Good, L., Awasthi, S. K., Dryselius, R., Larsson, O., and and Nielsen, P. E. (2001) Bactericidal antisense effects of peptide-PNA conjugates. Nat. Biotechnol. 19, 360-364.

\section{FIGURES AND SCHEMES}

a)

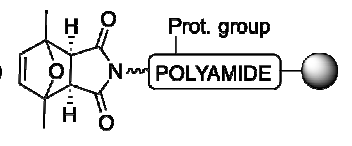

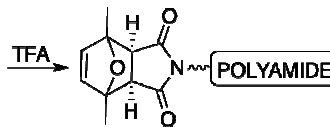

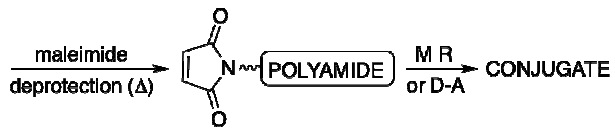

M R = Michael-type reaction D-A = Diels-Alder cycloaddition POLYAMIDE $=$ peptide, PNA, peptoid

b)

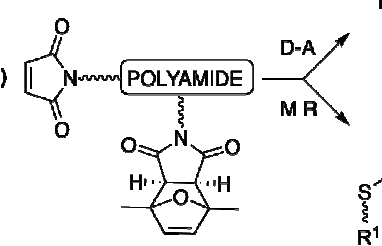

POLYAMIDE $=$ peptide, PNA

R = cholesterol, biotin, peptide (3- to 21-mer). oligonucleotide (phosphate or phosphorothioate linkages)

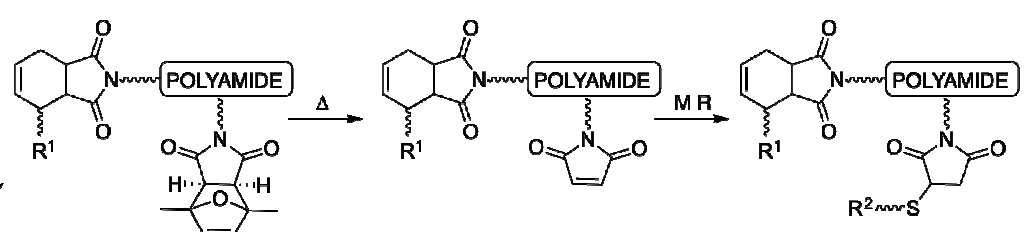

Scheme 1. a) General procedure for polyamide synthesis and conjugation. b) General structures of the conjugates prepared making use of two successive click reactions (peptide and PNA sequences are shown in Scheme 4; the structure of thiols and dienes is shown in Figure 1). 

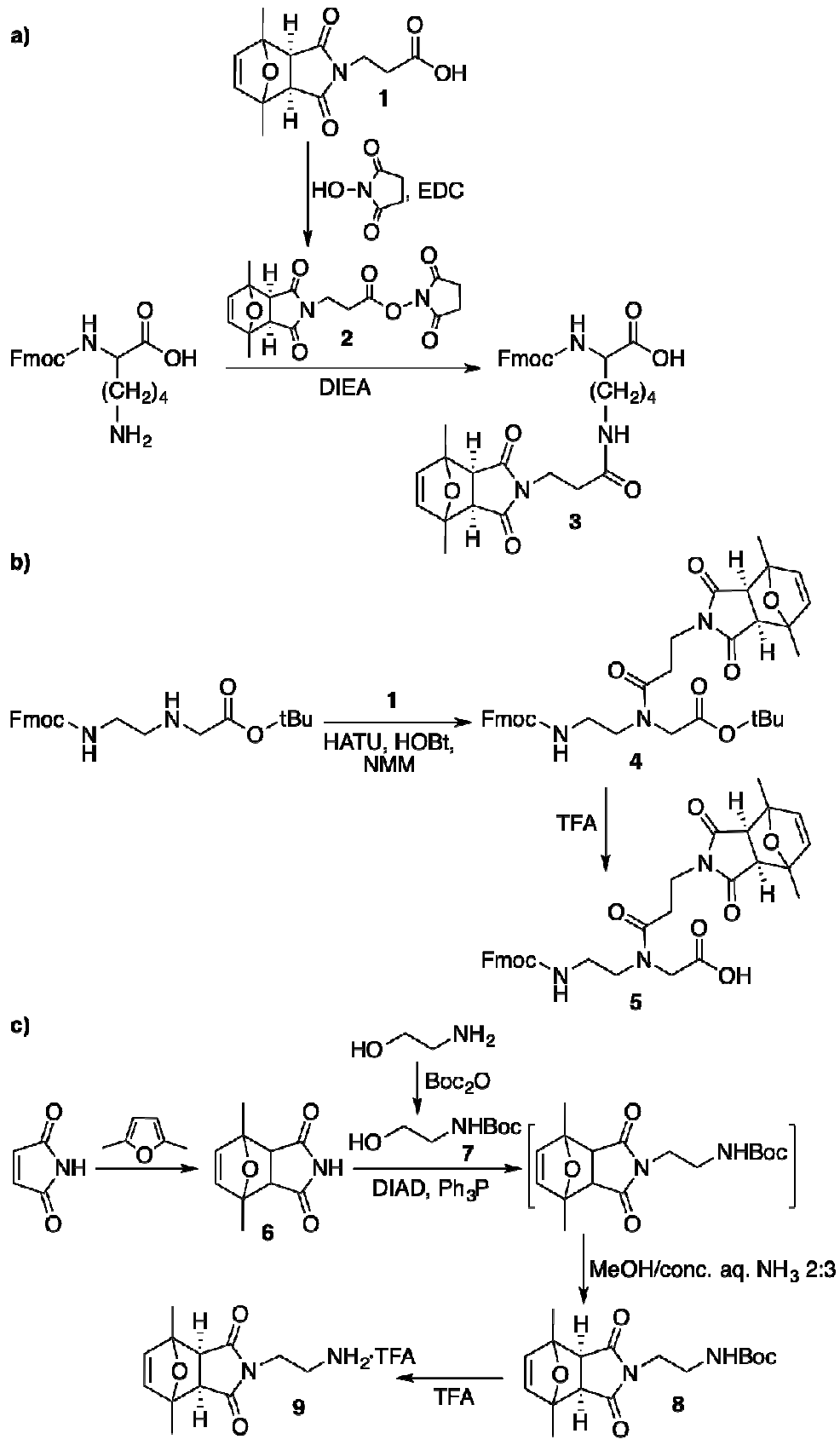

Scheme 2. Synthesis of compounds suitable for the introduction of protected maleimides into peptides (a), PNAs (b) and peptoids (c). 


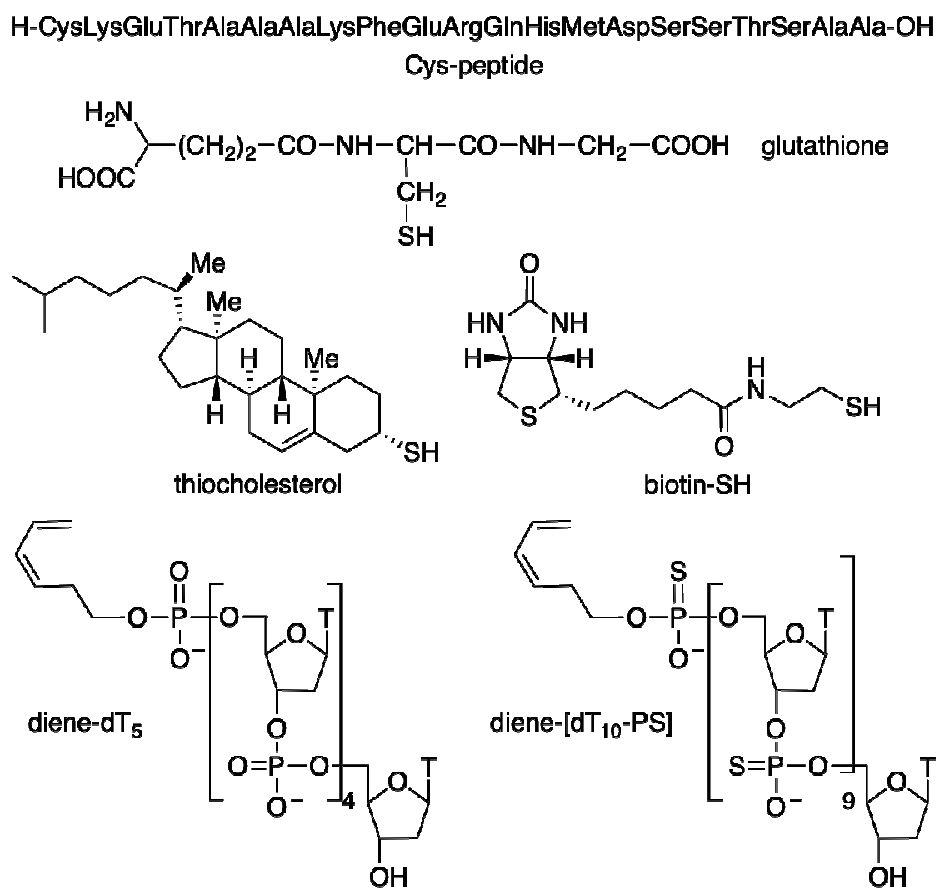

Figure 1. Structures of thiols and dienes used in conjugation reactions. 
a) $\mathrm{X}-\left(\mathrm{CH}_{2}\right)_{2} \mathrm{CO}$-Ala-Lys-Tyr- $\mathrm{Gly}-\mathrm{NH}_{2}$

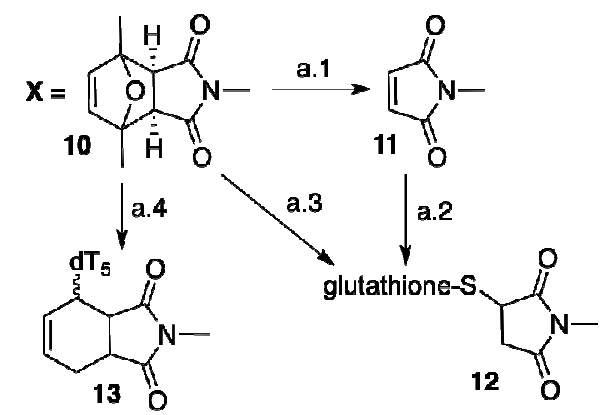

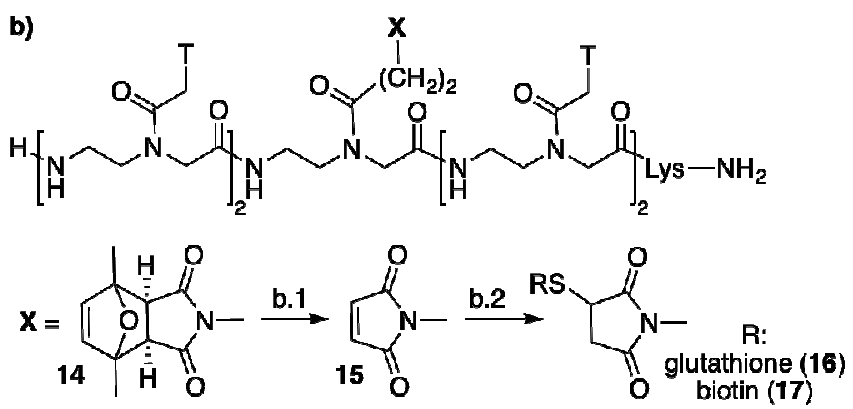

c) $\mathrm{X}-\left(\mathrm{CH}_{2}\right)_{2}-\mathrm{NH}-\mathrm{CH}_{2}-\mathrm{CO}-\mathrm{N}-\mathrm{CH}_{2}-\mathrm{CO}-\mathrm{N}-\mathrm{CH}_{2}-\mathrm{CO}-\mathrm{NH}_{2}$

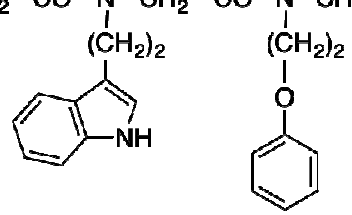

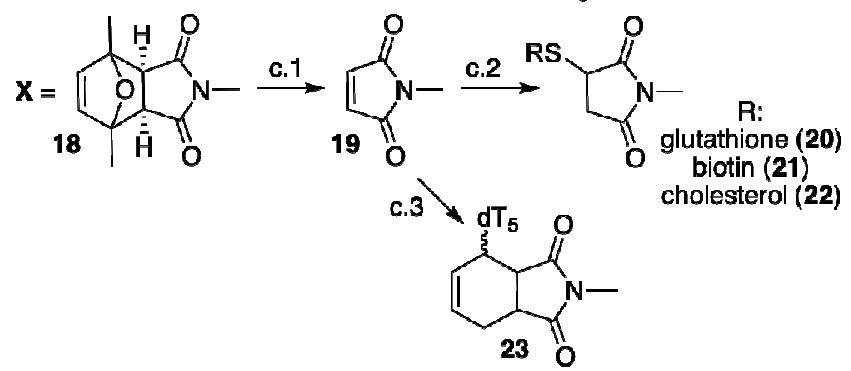

Reaction conditions/reagents: a.1: heating in toluene; a.2: + glutathione; a.3: heating in toluene in the presence of glutathione; a.4: heating in toluene in the presence of diene-dT $;$ b.1: microwave irradiation; b.2: + glutathione/biotin-SH; c.1: heating in toluene; c.2: + glutathione/biotinSH/thiocholesterol; c.3: + diene-dT 5

Scheme 3. Structures of peptide (a), PNA (b) and peptoid (c) incorporating a protected maleimide unit, and reactions subsequently carried out. 
a)

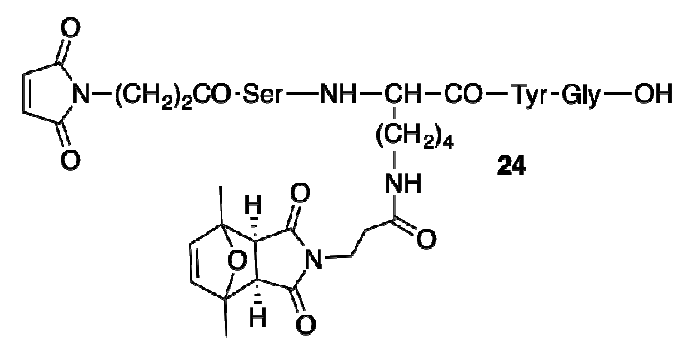

1) i) $\mathbf{2 4}+$ glutathione $\rightarrow \mathbf{2 5}$

ii) maleimide deprotection of $25 \rightarrow 26$

iii) 26 + diene-d $\mathrm{dT}_{5} \rightarrow \mathbf{2 7}$

2) i) $\mathbf{2 4}+$ diene-dT $\rightarrow \mathbf{2 8}$

ii) maleimide deprotection of $\mathbf{2 8} \rightarrow \mathbf{2 9}$

iii) $\mathbf{2 9}+$ glutathione $\rightarrow \mathbf{3 0}$

3) i) $\mathbf{2 4}+$ glutathione $\rightarrow \mathbf{2 5}$

ii) maleimide deprotection of $25+$ diene- $\mathrm{dT}_{5} \rightarrow 27$

b)

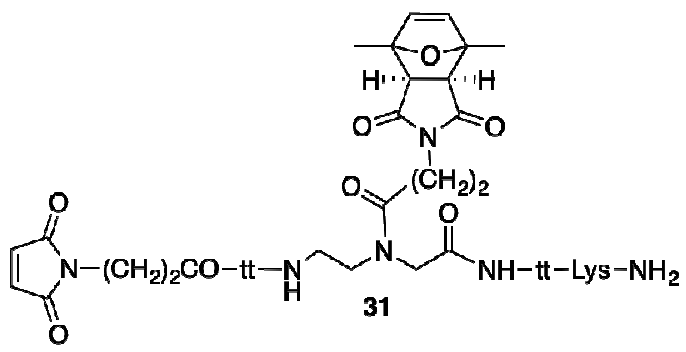

1) i) $31+$ biotin- $\mathrm{SH} \rightarrow 32$

ii) maleimide deprotection of $32 \rightarrow 33$

iii) $33+$ Cys-peptide $\rightarrow 34$

2) i) $\mathbf{3 1}+$ biotin- $\mathrm{SH} \rightarrow \mathbf{3 2}$

ii) maleimide deprotection of $32 \rightarrow 33$

iii) 33 + diene-[ $\left.\mathrm{dT}_{10}-\mathrm{PS}\right] \rightarrow 35$

3) i) $31+$ diene- $\left[\mathrm{dT}_{10}-\mathrm{PS}\right] \rightarrow-36$

ii) maleimide deprotection of $36 \rightarrow 37$

iii) $\mathbf{3 7}+$ Cys-peptide $\rightarrow \mathbf{3 8}$

c)

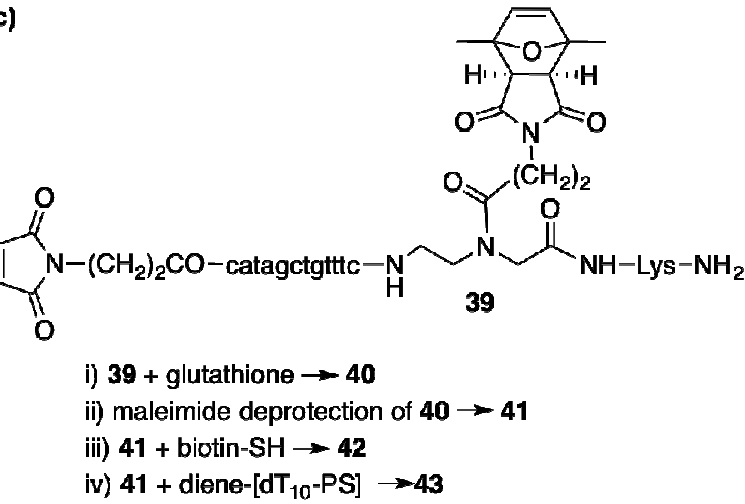

Scheme 4. Structures of peptide (a) and PNA scaffolds (b, c) incorporating two maleimides, one protected and one unprotected, used for the attachment of two different moieties, and subsequent deprotection and conjugation reactions. 


\section{TOC graphic:}

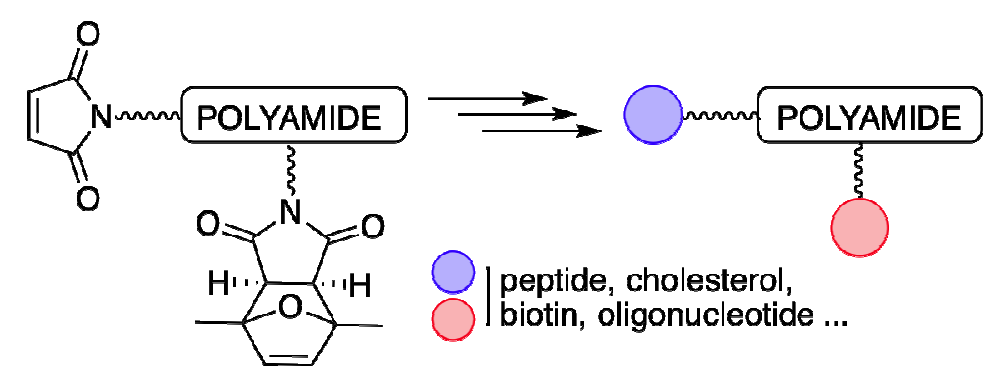

